\title{
Effects of nutrients enrichment on algal communities: an experimental in mesocosms approach
}

\author{
Efeitos do enriquecimento de nutrientes em comunidades de algas: \\ uma abordagem experimental em mesocosmos
}

Sirlene Aparecida Felisberto ${ }^{1}$, Josimeire Aparecida Leandrini ${ }^{2}$ and Liliana Rodrigues ${ }^{3}$

${ }^{1}$ Instituto de Ciências Biológicas, Programa de Pós-Graduação em Ecologia e Evolução, Universidade Federal de Goiás - UFG, Campus Samambaia, CP 131, CEP 74001-970, Goiânia, GO, Brazil e-mail: sirfe@hotmail.com

${ }^{2}$ Universidade Federal da Fronteira Sul - UFFS, Campus de Laranjeiras do Sul, Rua Oscar da Silva Guedes, 01, Vila Alberti, CEP 85303-775, Laranjeiras do Sul, PR, Brazil e-mail: jaleandri@gmail.com

${ }^{3}$ Programa de Pós-Graduação em Ecologia de Ambientes Aquáticos Continentais - PEA, Núcleo de Pesquisas em Limnologia, Ictiologia e Aquicultura - NUPÉLIA,

Universidade Estadual de Maringá - UEM, Bloco G-90, Av. Colombo, 5790, CEP 87020-900, Maringá, PR, Brazil e-mail: 1rodrigues@nupelia.uem.br

\begin{abstract}
Aim: The effect of different concentrations of nutrients on algal communities living at the bottom of mesocosms was examined; Methods: The experiment was carried out in the tributary of Rosana reservoir (Corvo river) from November $22^{\text {nd }}$ to December $16^{\text {th }}$ of 2003. Mesocosms were set up in triplicate, with four treatments: nitrogen $(\mathrm{N})$; phosphorus (P); nitrogen plus phosphorus (NP); plus a control treatment $(\mathrm{C})$, consisting in addition of water from the reservoir; Results: Results of the Principal Components Analysis applied on the abiotic variables have shown that two axes explained $93.6 \%$ of the total variability ( 69.6 and $23.9 \%$, respectively). It was possible to identify a group of $\mathrm{P}$ (positive) and $\mathrm{N}$ (negative) treatments of axis 1 . The addition of nutrients in the experiment resulted in changes in algal composition. Mean values of density ranged from 8.383 to 34.510 ind. $\mathrm{mL}^{-1}$. Higher densities occurred in the phosphorus and nitrogen plus phosphorus treatments. The most representative classes were Zygnemaphyceae, Chlorophyceae, Bacillariophyceae and Cyanobacteria, both in density and species richness; Conclusions: Phosphorus seems to be beneficial to green algae in general, since a marked increase in Zygnemaphyceae and Chlorophyceae was found in the treatments containing phosphorus and nitrogen plus phosphorus. In the nitrogen treatment, however, green algae decreased dramatically, while Cyanobacteria remained constant, indicating their capacity to live in changed environments and confirms the limiting role played by phosphorus on the algal groups.
\end{abstract}

Keywords: benthic algal, phosphorus, nitrogen, Zygnemaphyceae, Chlorophyceae.

Resumo: Objetivo: Este trabalho teve como objetivo avaliar a resposta das comunidades algais presente no sedimento de mesocosmos em diferentes concentraçóes de nutrientes; Métodos: $\mathrm{O}$ experimento foi realizado no afluente do reservatório de Rosana (rio do Corvo) no período de 22 de novembro a 16 de dezembro de 2003. Os mesocosmos foram preparados em triplicatas e em quatro tratamentos: $(\mathrm{N})$ com adição de nitrogênio; (P) adição de fósforo; (NP) adição de nitrogênio + fósforo e o tratamento controle (C) com adição de água do reservatório; Resultados: Os resultados da Analise de Componentes Principais aplicados com dados abióticos mostram que os dois primeiros eixos explicaram $93,6 \%$ da variabilidade total dos dados (69,6 e 23,9\%, respectivamente). Com isso foi possível identificar grupos de variáveis relacionadas ao tratamento com $\mathrm{P}$ (positivamente) e outro com nitrogênio (negativamente) no eixo 1. A adição dos nutrientes provocou alteraçóes nos diferentes grupos de algas, com valores médios da densidade variando entre 8.383 to 34.510 ind. $\mathrm{mL}^{-1}$. Maior densidade foi observada no tratamento com P e NP, respectivamente. Zygnemaphyceae, Chlorophyceae, Bacillariophyceae e Cyanobacteria foram às classes mais representativas, tanto em densidade quanto em riqueza de espécies; Conclusóes: O P parece beneficiar as algas verdes em geral, uma vez que no tratamento com P e com NP houve aumento acentuado de Zygnemaphyceae e Chlorophyceae. Já no tratamento com $\mathrm{N}$ as algas verdes diminuíram drasticamente, enquanto as Cyanobacteria mantiveram constantes, mostrando a capacidade que esse grupo tem em se manter em ambientes alterados e confirma o papel limitante que o P exerce sobre os grupos algais.

Palavras-chave: algas bênticas, fósforo, nitrogêno, Zygnemaphyceae, Chlorophyceae. 


\section{Introduction}

In the decade of 1960 and 1970, two perspectives of the relationship between nutrient levels and algal growth (ecosystem and an autecological approach), propitiated new insights about nutrient cycling, anthropogenic eutrophization, algal community structure, and interactions among algae and other organisms (Borchadt, 1996). A perspective of the problems related with the eutrophization can be gotten from the analysis of raised resources required to development of algae, since phosphorus and nitrogen are probably the most likely to be limitant of algal growth (Borchadt, 1996).

Experimentally, biomass has a positive response to increased water nutrients availability, considering the status of nutrient from periphyton a good predictor (França et al., 2009). The structure of the periphytic algae communities can be altered by artificial addition of nutrients (Murakami and Rodrigues, 2009). In addition the species structure (chlorophytes and diatoms) were sensible to phosphorus availability and P-addition (Ferragut and Bicudo, 2009), showing that the phosphorus, especially, may be considered a driver of periphytic algae (Ferragut and Bicudo, 2009; Murakami and Rodrigues, 2009). Preliminary synthesis of the evaluation of nutrient limitation to algal growth reveal phosphorus as the most limiting element in reservoirs (Huszar et al., 2005).

In Brazil, the effect of enrichment with $\mathrm{N}$ and $\mathrm{P}$ on attached algae (periphyton), either in biomass response (Cerrao et al., 1991; Engle and Melack, 1993; Mendes and Barbosa, 2002; França et al., 2009; Oliveira et al., 2010), or on the community structure approaches (Murakami and Rodrigues, 2009; Ferragut and Bicudo, 2009, 2010) are still scarce. Thus, this study broaden the understanding of the influence of concentration of nutrients in the structure of algae at the bottom of mesocosms artificially enriched with individual or combined actions of $\mathrm{N}$ and $\mathrm{P}$.

Considering that nitrogen and phosphorus constitute the most important limiting nutrients to algal growth, we aimed to assess the effects of different concentrations of nutrients on algal communities living at the bottom of mesocosms. If algal growth is dependent upon nutrients, then we hypothesize that the algal community - density and species composition, should be positively correlated with nutrient concentrations.

\section{Material and Methods}

The Rosana reservoir is located at the final stretch of the Paranapanema river, locally known as "Pontal do Paranapanema". The selected site to conduct this study is a tributary of this reservoir (Corvo river $22^{\circ} 39^{\prime} \mathrm{S}$; $052^{\circ} 46^{\prime} \mathrm{W}$, Figure 1), which is located near the reservoir dam, in the State of Paraná.

The experiment was carried out from November $22^{\text {nd }}$ to December $16^{\text {th }} 2003$. Twelve mesocosms were designed for four treatments (triplicate, stage 1, Figure 2) built of polyethylene bags and fixed randomly on the lake $2 \mathrm{~m}$ distant one from another to prevent contamination among them. They were suspended in the water column $(1 \mathrm{~m}$ depth) by a float attached to a permanent buoy. Mesocosms with a capacity of $1000 \mathrm{~L}$ and a depth of $1 \mathrm{~m}$ were installed on November $21^{\text {st }}$, without contact with the sediment, filled with water from the reservoir itself (stage 2-3, Figure 2). The mesocosms were set up in triplicate, with four treatments: a control treatment $(\mathrm{C})$ consisting on the addition of water from the reservoir $=2 \mu \mathrm{g} \mathrm{N}-\mathrm{NO}_{3}{ }^{-} \mathrm{L}^{-1}$ and $4 \mu \mathrm{g} \mathrm{P}_{-} \mathrm{PO}_{4}^{3-} \mathrm{L}^{-1}$; Nitrogen treatment $(\mathrm{N})$ added $=1000 \mu \mathrm{g} \mathrm{N}-\mathrm{NO}_{3}{ }^{-} \mathrm{L}^{-1}$; phosphorus treatment $(\mathrm{P})$ added $=40 \mu \mathrm{g} \mathrm{P}_{-} \mathrm{PO}_{4}^{3-} \mathrm{L}^{-1}$ and nitrogen plus phosphorus treatments $(\mathrm{N}+\mathrm{P})$

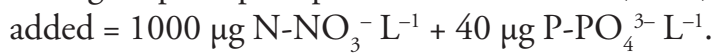
Nutrients were introduced in the treatments only in November $22^{\text {th }}$ (stage 4, Figure 2); in the initial phase of experiment and control treatment were these existing concentrations in water of the environment (Figure 2).

For determination of biological variables (algal density and species composition) samples were obtained by taking 5-10 mL from the bottom of each mesocosm after emptying them carefully, during the last day, on December $16^{\text {th }}$ (stage 5, Figure 2). The samples were fixed and preserved with Lugol's solution. Quantitative study was carried out according to Utermöhl (1958), using an Olympus brand CK-2 inverted microscope. The algae were quantified (cells per liter) in the sedimentation chamber using the random fields method, until the rare species curve was reached according to Bicudo (1990). Only living algae were counted for the densities calculation and algae filaments were counted as filament numbers. The taxa considered abundant were those with densities higher than the average of each sample (Lobo and Leighton, 1986).

Abiotic data were collected simultaneously with the biotic data, and were supplied by Laboratório de Limnologia Básica, from Núcleo de Pesquisa em 


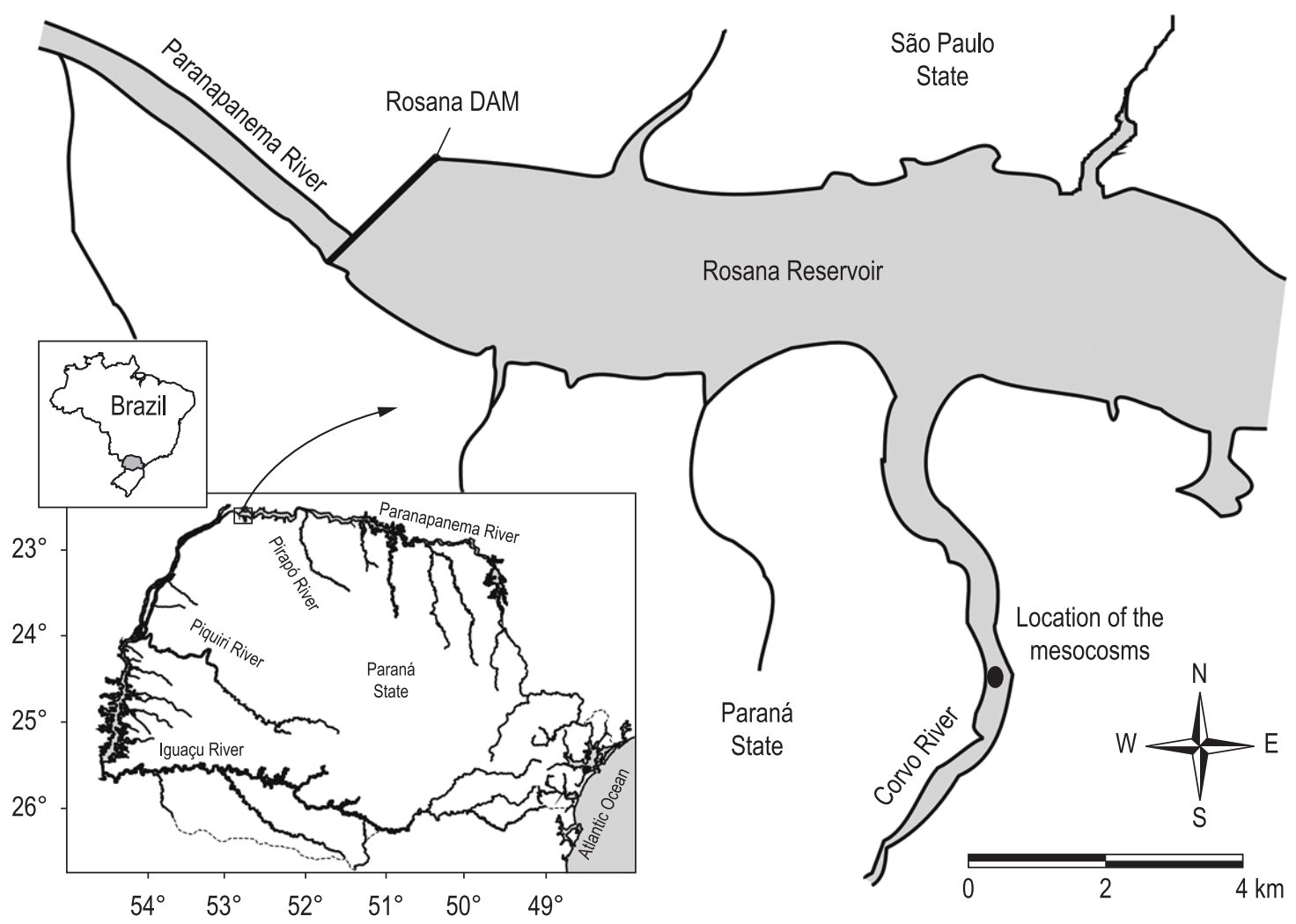

Figure 1. Location of the Corvo river, tributary of the Rosana reservoir (Paranapanema river basin), where were installed the mesocosms.

Limnologia, Ictiologia e Aquicultura - Universidade Estadual de Maringá (NUPELIA/UEM). The following physical and chemical water variables were analyzed: water temperature, electric conductivity, dissolved oxygen (Golterman et al., 1978), turbidity, alkalinity (Golterman and Clymo, 1971). Total suspended material (Wetzel and Likens, 1991), total nitrogen (Valderrama, 1981), ammonium (Solorzano, 1969), total dissolved phosphorus and orthophosphate (Golterman et al., 1978), and total phosphorus (Valderrama, 1981).

Principal Components Analysis (PCA) was used to reduce dimensionality of abiotic (12 variables) data, which were log-transformed, according to equation $\log (\mathrm{n}+1)$. The software used was PC-ORD version 5.0 for Windows (McCune and Mefford, 2006). Principal components axes retained for interpretation were those that presented eigenvalues higher than the eigenvalues produced by the Broken-Stick model (Jackson, 1993).

In order to compare the mean values for density in the different treatments, we applied an analysis of variance (one-way ANOVA) with significant level $(p)=0.05$, using the software StatSoft 7.1. Kolmorov-Smirnov and Bartlett Tests were carried out to verify if the variables satisfied the assumptions of normality and homoscedasticity, respectively, and were performed through the software Statistica 7.1 (StatSoft, 2005). When such differences were observed, Tukey's Test was carried out.

\section{Results}

The water physical and chemical parameter values, water temperature, conductivity, dissolved oxygen, and turbidity showed steadier values, while other variables, such as nutrients, showed greater variation. Total nitrogen and ammonium ion were higher at mesocosms with nitrogen and nitrogen plus phosphorus treatments while total phosphorus was higher at mesocosms with phosphorus and nitrogen plus phosphorus treatments (Table 1).

Results of the Principal Components Analysis applied on the abiotic variables are shown in Figure 3 and Table 2. Two axes were retained for interpretation and together they showed $93.6 \%$ of the total variability (69.6 and $23.9 \%$, respectively). It is possible to identify a group of $\mathrm{P}$ (positively) and $\mathrm{N}$ (negatively) treatments of axis 1 . The highest values of orthophosphate and total dissolved phosphorus, corresponding to the $\mathrm{P}$ treatment while 

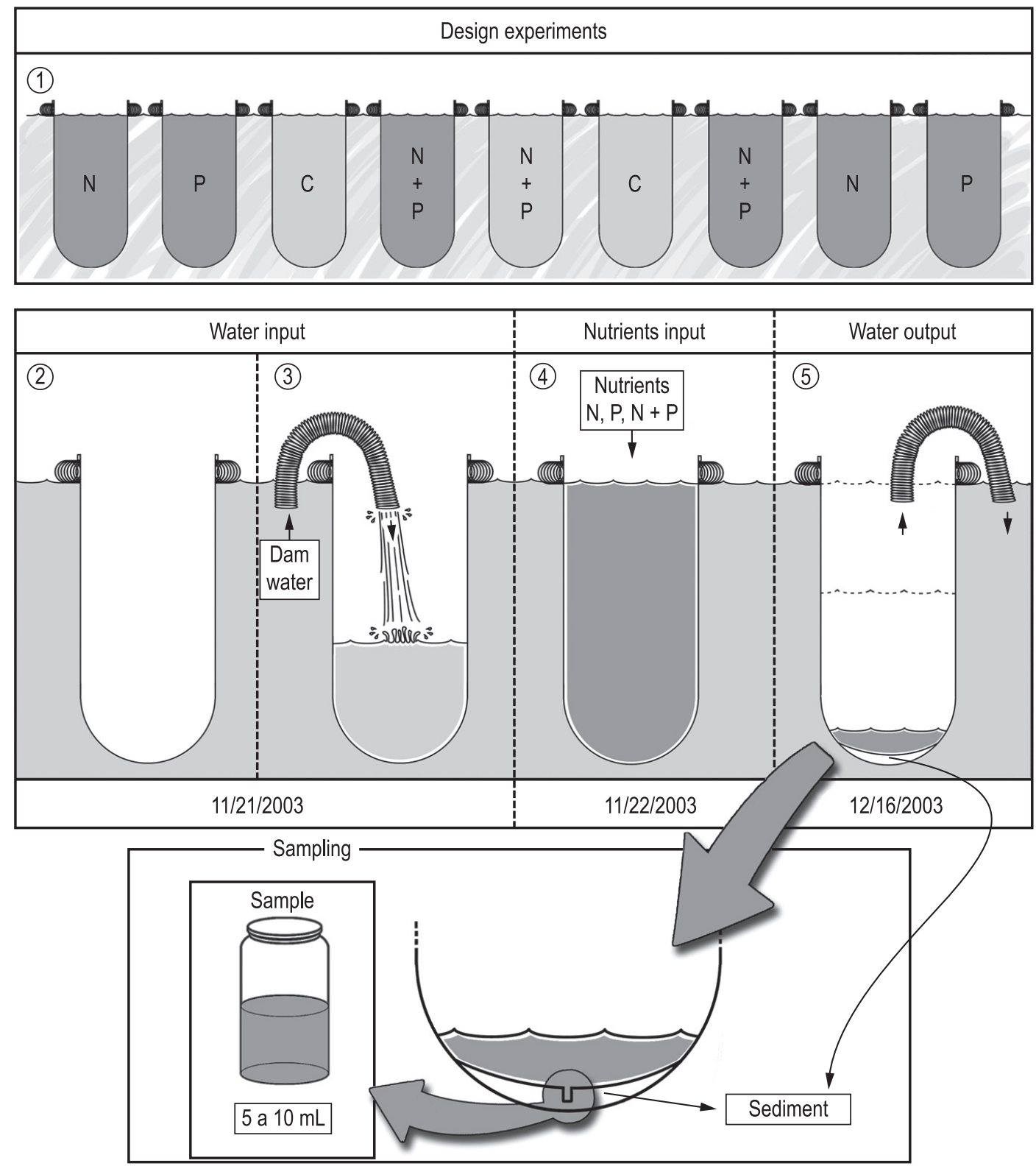

Figure 2. Schedule of the design experiments with different treatments of mesocosms installed in the Corvo river (Rosana reservoir). Stage 1 - mesocosms were randomly designed (in triplicate) with four treatments: Control (C); Nitrogen $(\mathrm{N})$; phosphorus $(\mathrm{P})$ and nitrogen plus phosphorus $(\mathrm{N}+\mathrm{P})$. Stage 2-3 - mesocosm were filled with water from the reservoir itself. Stage 4 - nutrients were introduced in the mesocosms. Stage 5 - In each mesocosms, after emptying carefully, samples were obtained by taking $5-10 \mathrm{~mL}$ from the bottom. Ilustração: C.Y. Joko, E.A. Murakami $\&$ S.A. Felisberto.

the highest values of molar ratio and ammonium ion corresponding to the $\mathrm{N}$ treatment (Figure 3).

The second PCA axis separated the treatments mainly with respect to $\mathrm{C}$ (positively) and NP (negatively). The highest values of total phosphorus and total suspended material corresponding to NP treatment, while orthophosphate correlated with highest values in $\mathrm{C}$ treatment (Figure 3).

A total of 200 taxa were identified, distributed among 11 taxonomic classes (Bacillariophyceae,
Chlorophyceae, Chrysophyceae, Cryptophyceae, Cyanophyceae, Dinophyceae, Euglenophyceae, Oedogoniophyceae, Ulothricophyceae, Xanthophyceae and Zygnemaphyceae). We recorded the occurrence of 121 taxa in the control treatment, 118 taxa in the $\mathrm{N}$ treatment, 141 taxa in the $\mathrm{P}$ treatment and 133 in the $\mathrm{N}+\mathrm{P}$ treatment. The most representative classes in species richness were Zygnemaphyceae, Chlorophyceae, Bacillariophyceae and Cyanobacteria. In general, 
Table 1. Values (average) and standard deviation obtained for physical and chemical parameters in each treatment. Control treatment $(\mathrm{C})$; nitrogen treatment $(\mathrm{N})$; phosphorus treatment $(\mathrm{P})$ and nitrogen plus phosphorus treatments (NP).

\begin{tabular}{lcccr}
\hline \multicolumn{1}{c}{ Parameters $/$ Treatments } & $\mathrm{C}$ & $\mathrm{N}$ & $\mathrm{P}$ & $\mathrm{NP}$ \\
\hline Water temperature $\left({ }^{\circ} \mathrm{C}\right)$ & $26.6 \pm 0.1$ & $26.6 \pm 0.0$ & $26.3 \pm 0.5$ & $26.7 \pm 0.0$ \\
Conductivity $\left(\mu \mathrm{S} . \mathrm{cm}^{-1}\right)$ & $35.6 \pm 1.2$ & $40.2 \pm 0.8$ & $34.2 \pm 0.4$ & $39.0 \pm 0.4$ \\
Dissolved oxygen $\left(\mathrm{mg} . \mathrm{L}^{-1}\right)$ & $3.8 \pm 0.6$ & $3.2 \pm 0.7$ & $4.7 \pm 0.4$ & $4.9 \pm 0.3$ \\
Turbidity $(\mathrm{NTU})$ & $2.4 \pm 0.5$ & $2.5 \pm 0.5$ & $1.0 \pm 0.0$ & $2.9 \pm 0.7$ \\
Alkalinity $\left(\mathrm{mEq} . \mathrm{L}^{-1}\right)$ & $206.0 \pm 6.1$ & $247.4 \pm 20.3$ & $197.2 \pm 3.5$ & $234.7 \pm 7.2$ \\
Total suspended material $\left(\mathrm{mg} . \mathrm{L}^{-1}\right)$ & $0.68 \pm 0.1$ & $1.17 \pm 0.2$ & $0.57 \pm 0.1$ & $1.78 \pm 0.3$ \\
Total phosphorus $\left(\mu \mathrm{\mu g} \mathrm{L}^{-1}\right)$ & $18.6 \pm 0.8$ & $19.9 \pm 2.5$ & $24.9 \pm 1.6$ & $26.0 \pm 4.0$ \\
Orthophosphate $\left(\mu \mathrm{g} \cdot \mathrm{L}^{-1}\right)$ & $8.2 \pm 0.7$ & $7.3 \pm 1.2$ & $7.5 \pm 1.1$ & $6.9 \pm 1.5$ \\
Total dissolved phosphorus $\left(\mu \mathrm{\mu g} \mathrm{L}^{-1}\right)$ & $11.01 \pm 0.8$ & $7.09 \pm 0.8$ & $8.79 \pm 0.2$ & $8.73 \pm 1.0$ \\
Total nitrogen $\left(\mu \mathrm{g} . \mathrm{L}^{-1}\right)$ & $208.4 \pm 11.2$ & $490.6 \pm 75.8$ & $181.7 \pm 17.9$ & $488.5 \pm 17.2$ \\
Ammonium ion $\left(\mu \mathrm{g} . \mathrm{L}^{-1}\right)$ & $4.8 \pm 0.3$ & $9.1 \pm 2.0$ & $2.3 \pm 0.5$ & $6.4 \pm 2.2$ \\
Molar ratio $\mathrm{N}: \mathrm{P}\left(\mu \mathrm{g} . \mathrm{L}^{-1}\right)$ & $11: 1$ & $25: 1$ & $7: 1$ & $19: 1$ \\
\hline
\end{tabular}

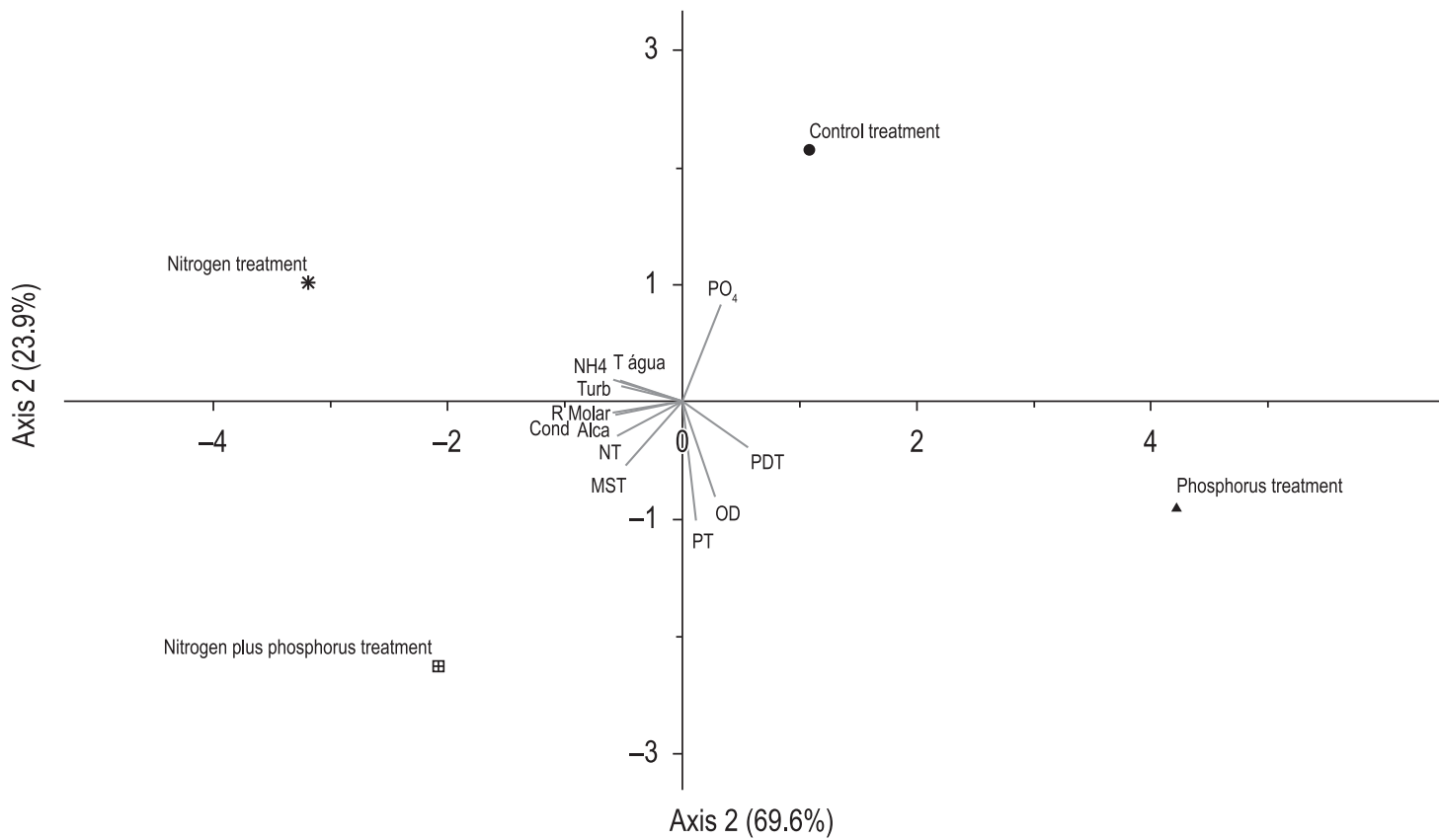

Figure 3. Biplot of principal component analysis with ordering the treatments studied in relation to abiotic parameters. Orthophosphate $=$ PO4; Total dissolved phosphorus $=$ PDT; Total phosphorus = PT; Dissolved oxygen = OD; Total suspended material $=$ MST; Total nitrogen $=$ NT; Alkalinity $=$ Alca.; Conductivity $=$ Cond.; Molar ratio N:P $=$ R molar; Turbidity $=$ Turb.; Ammonium ion $=$ NH4; Water temperature $=$ T água .

the highest species in numbers were: Staurastrum (29 species), Cosmarium (21) and Staurodesmus (11).

Mean values density and standard deviation values (between parentheses) ranged from 8.383 (6.7) ind. $\mathrm{mL}^{-1}$ in the control treatment; 11.154 (7.7) ind. $\mathrm{mL}^{-1}$ in the $\mathrm{N}$ treatment; 24.799 (18.3) ind. $\mathrm{mL}^{-1}$ in the $\mathrm{P}$ treatment; to 34.511 (14) ind. $\mathrm{mL}^{-1}$ in the $\mathrm{N}+\mathrm{P}$ treatment. Although the ANOVA for density in the different treatments was not significant $\left(\mathrm{F}_{3,8}=3.7195 ; p=0.06098\right)$, higher density values were observed in the $\mathrm{N}+\mathrm{P}$ treatment and also in $\mathrm{P}$ treatment (Figure 4).

The density contribution of the four more important taxonomic classes in each treatment (Figure 5) was mainly for Zygnemaphyceae (C - 49\%; $\mathrm{N}-40 \% ; \mathrm{N}+\mathrm{P}-39 \%$, and $\mathrm{P}-31 \%$ ) and Bacillariophyceae $(\mathrm{N}-18 \%$; $\mathrm{C}$ and $\mathrm{P}-17 \%$; and $\mathrm{N}+\mathrm{P}-12 \%)$, while Chlorophyceae $(\mathrm{P}-40 \%$; $\mathrm{N}+\mathrm{P}-30 \% ; \mathrm{C}-16 \%$, and $\mathrm{N}-7 \%$ ) and Cyanophyceae (N - 16\%; N+P - 10\%; C - 9\%, and $\mathrm{P}-8 \%$ ) showed greater variation, especially 
Table 2. Correlation and performance values obtained through Principal Component Analysis (PCA) to mesocosms installed in the Corvo River.

\begin{tabular}{lcc}
\hline \multicolumn{1}{c}{ Parameters } & Axis 1 correlation & Axis 2 correlation \\
\hline Water temperature & -0.8879 & 0.1695 \\
Conductivity & -0.9858 & -0.0918 \\
Dissolved oxygen & 0.4582 & -0.8076 \\
Turbidity & -0.8652 & 0.1270 \\
Alkalinity & -0.9730 & -0.1108 \\
Total suspended material & -0.8249 & -0.5298 \\
Total phosphorus & 0.1896 & -0.9811 \\
Orthophosphate & 0.5283 & 0.8066 \\
Total dissolved phosphorus & 0.9163 & -0.3841 \\
Total nitrogen & -0.9492 & -0.2962 \\
Ammonium ion & -0.9837 & 0.1787 \\
Molar ratio N:P & -0.9952 & -0.0016 \\
Eigenvalue & 8.359 & 2.879 \\
\% variance & 69.662 & 23.992 \\
Broken-stick & 3.103 & 2.103 \\
\hline
\end{tabular}

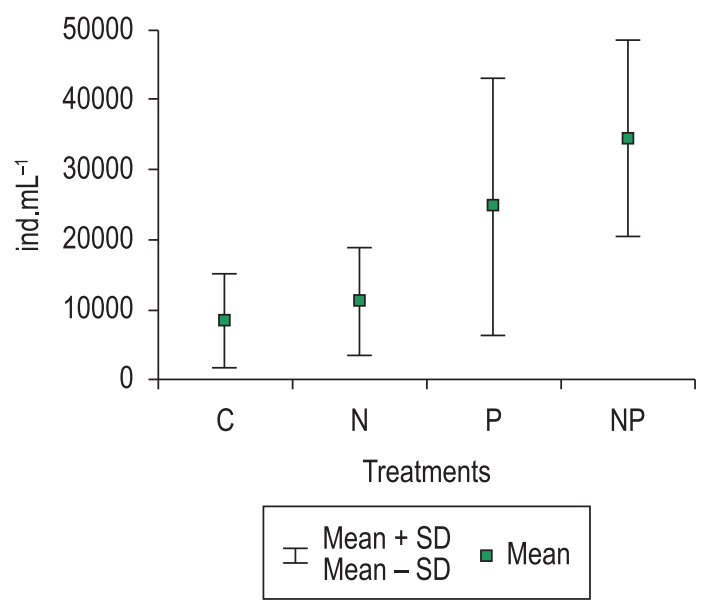

Figure 4. Algal density in different treatments of mesocosms installed in the Corvo river (Rosana reservoir). Control treatment $(\mathrm{C})$; nitrogen treatment $(\mathrm{N})$; phosphorus treatment $(\mathrm{P})$ and nitrogen plus phosphorus treatments (NP).

when comparing treatment with $\mathrm{P}$ and $\mathrm{N}$, in which both classes had opposed density. Chlorophyceae presented more density in $\mathrm{P}$ treatment, decreasing drastically in $\mathrm{N}$ treatment (Figure 5).

In relation to abundant species, mesocosm that showed largest number of taxa was $\mathrm{P}$ treatment (32). In the phosphorus treatment abundant taxa corresponded to $82.2 \%$ total density. Monoraphidium cf. contortum (Thur.) Kom.-Legn., Fragilaria capucina Desm., Drepanochloris uherkovichii Marvan, Cosmarium regnesii Reinsch, Staurastrum tetracerum (Kütz.) Ralfs, Gloeocapsa sp. and Staurodesmus dejectus (Bréb.) Teil. were the most abundant species in the community, contributing with 52\% (Figure 6).

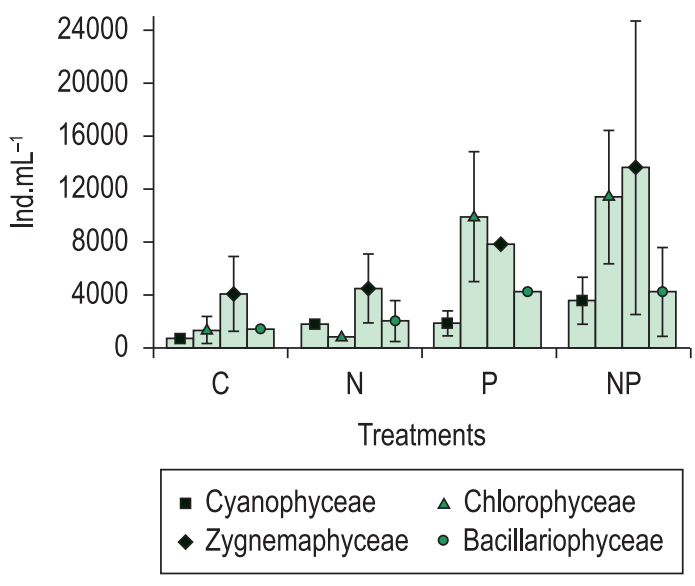

Figure 5. Algal density of the most representative classes in different treatments of mesocosms installed in the Corvo river (Rosana reservoir). Control treatment (C); nitrogen treatment $(\mathrm{N})$; phosphorus treatment $(\mathrm{P})$ and nitrogen plus phosphorus treatments (NP).

In the control treatment 31 abundant taxa corresponded to $78.1 \%$ total density. Staurastrum tetracerum, Fragilaria capucina and Cosmarium regnesii contributed with $26 \%$ of the algal community (Figure 6).

In the treatment where nitrogen was added, 26 abundant taxa corresponded to $80 \%$ of total density. Staurastrum tetracerum, Trachelomonas sp., Pseudanabaena cf. moniliformes Kom. \& Kling, Gomphonema parvulum Kütz., Fragilaria capucina, Peridinium sp. and Lyngbya cf. perelegans (Lemm.) Anag. \& Kom. contributed to $50 \%$ of the algal community (Figure 6).

In the treatment involving the combined addition of $\mathrm{N}+\mathrm{P}$, the most abundant species corresponded 


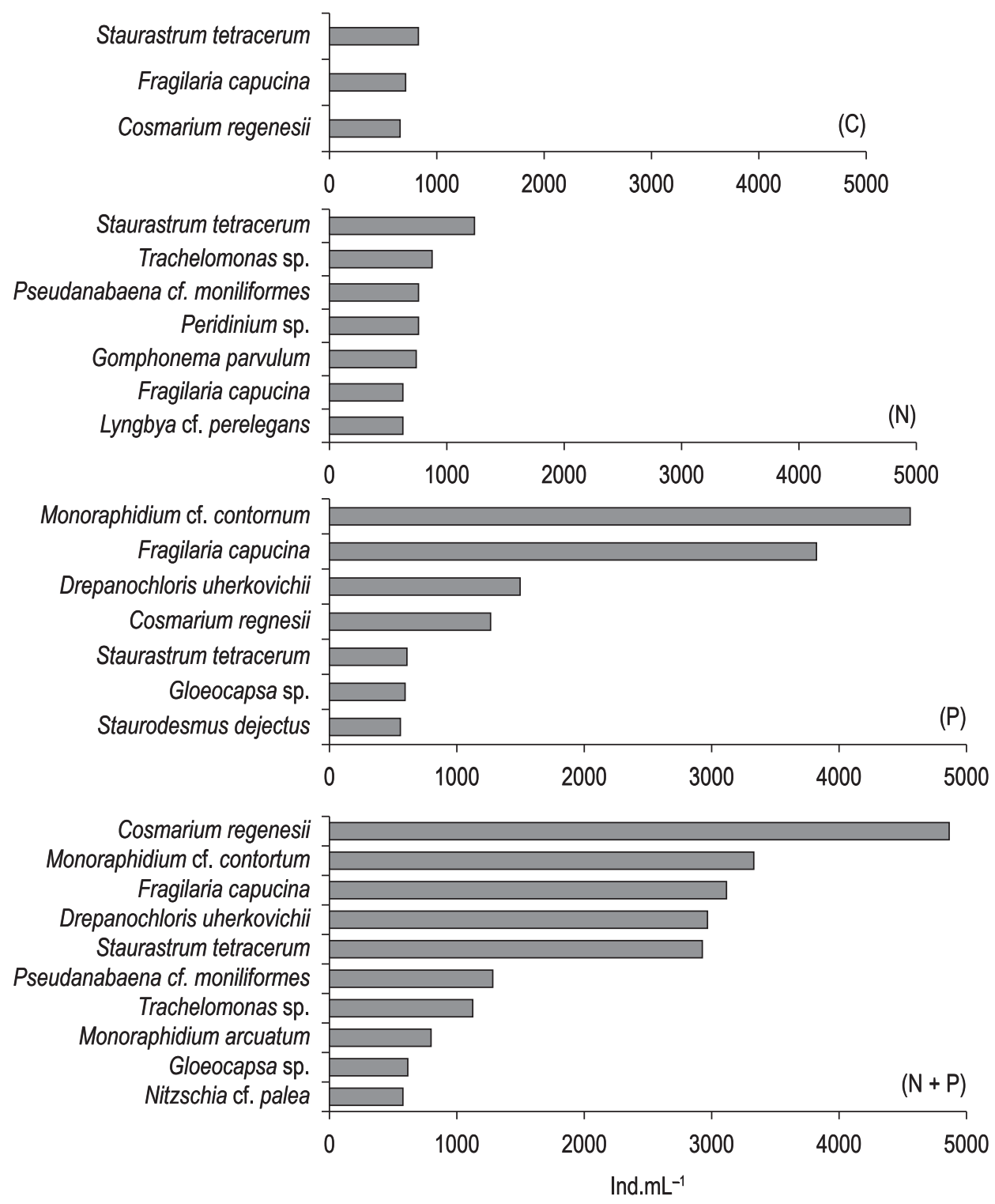

Figure 6. Abundant species contribution in each treatment of mesocosms. Control treatment (C); Nitrogen treatment $(\mathrm{N})$; phosphorus treatment $(\mathrm{P})$ and nitrogen plus phosphorus treatments $(\mathrm{N}+\mathrm{P})$.

to $81.2 \%$ total density. Cosmarium regnesii, Monoraphidium cf. contortum, Fragilaria capucina, Drepanochloris uherkovichii, Staurastrum tetracerum, Pseudanabaena cf. moniliformes, Trachelomonas sp., Monoraphidium arcuatum (Korsh.) Hind., Gloeocapsa sp. and Nitzschia cf. palea (Kütz.) Smith, what contributed to $63 \%$ of the algal community (Figure 6).

\section{Discussion}

When algae compete for phosphorus and nitrogen separately, absolute quantities of these elements should be responsible for the dominance of some taxa and elimination of others (Grover, 1989; Borchardt, 1996; Bulgakov and Levich,
1999; Stelzer and Lamberti, 2001). In the study, addition of nutrients $\mathrm{N}$ and $\mathrm{P}$, either individually or in combination, affected the density of algae community.

Treatment with the addition of $\mathrm{P}$ was associated with greater availability of $P$, since that ration $\mathrm{N}: \mathrm{P}$ was equal 7:1 and Zygnemaphyceae was more predominant. Despite the ration $\mathrm{N}: \mathrm{P}$ add much (19:1) in the treatment combined with $\mathrm{N}+\mathrm{P}$, the green algae continued more predominant, represented primarily by Chlorophyceae and then Zygnemaphyceae. In literature there is a discussion regarding to what is optimum for algae growth in relation at the N:P ration. Green algae attain their maximum biomass at the $\mathrm{N}: \mathrm{P}$ ratios $=20: 1$ 
and 50:1, while Cyanobacteria and diatoms have an optimum at $\mathrm{N}: \mathrm{P}$ ratio $=2-5: 1$ (Bulgakov and Levich, 1999). Schindler and Smith apud Levich and Bulgakov (1992) indicated that, at the atomic $\mathrm{N}: \mathrm{P}$ ratio less than 25:1, the Cyanobacteria prevails in the phytoplankton, meanwhile the increase of this ratio up to 25:1 and more leads to predominance of green and diatom algae. We found a different relationship, once that green algae occurred in treatments with ration $\mathrm{N}: \mathrm{P}$ that varied between 7-19:1. According to Huszar et al. (2000) and Biggs (1996), Chlorophyceae and Zygnemaphyceae are represented especially by ubiquitous species common in eutrophic environments. Consequently, the relative quantity of essential nutrients required for growth and reproduction is different among the species.

The inflow of phosphorus promotes an increase of Chlorophyceae, because it can assimilate and accumulate $\mathrm{P}$ from the sediment faster when resuspended, revealing that sediment is an important source of P (Havens et al., 1999; Dodds, 2003). This group contributed the most toward species richness in all treatments. The limiting role played by phosphorus in composition of the attached algae has already been demonstrated (Ferragut and Bicudo, 2009, 2010; Murakami and Rodrigues, 2009), as well as on their biomass (Oliveira et al., 2010; Mendes and Barbosa, 2002).

A great abundance of Monoraphidium cf. contortum and D. uherkovichii can be related to the higher disponibility of phosphorus. The genus Monoraphidium is commonly associated with shallow and enriched environments (Reynolds et al., 2002), high phosphorus concentrations, and low $\mathrm{N}: \mathrm{P}$ ratios (Kononen, 1988; Kuosa, 1988).

Cyanobacteria can store essential metabolic nutrients within their cytoplasm, especially under excessive supply conditions. Another advantage of the Cyanobacteria is nitrogen fixation, which provides them a simple nutritional requirement, even under conditions predominantly limited by nitrogen. Most Cyanobacteria accumulate polyphosphate granules when the cells are P-rich and they are often large enough to be distinguished easily with the light microscope. These features can be useful when assigning nutrient dynamics at a site (Kelly and Whitton, 1998). In order to optimize their position and thus find a suitable niche for survival and growth, Cyanobacteria use different environmental stimulis (e.g. light, chemical compounds, temperature). In addition, the protein phycobilin, together with chlorophyll- $a$, allows the Cyanobacteria to effectively absorb light energy and live in environments with low intensity of light. Therefore, this class has a competitive advantage in more turbid lentic environments, and is also capable of growing "in the shade" of other organisms (Chorus and Bartram, 1999). In Rosana reservoir tributary, without the addition of nutrients, Cyanobacteria were prominent and represented one of the most important components in the phytoplankton (Borges et al., 2008).

Many Euglenophyceae species are inhabitants of interface (water-air, sediment-water), much probably with a competitive advantage due to their periphytic habit (Rosowski, 2003). This possibly favored the abundance of Trachelomonas sp. at the bottom of treatments with the addition of $\mathrm{N}$ and $\mathrm{N}+\mathrm{P}$.

Diatoms were the dominant algal group on periphyton community structure, with several taxa responding primarily to nutrient ratio and total nutrient concentration (Stelzer and Lamberti, 2001). During the experiment, in the competition of the species for nutrients, Grover (1989) suggested that Synedra radians and Fragilaria capucina were good competitors for P. In the present study, Fragilaria capucina was highly abundant, mainly in $\mathrm{P}$ and $\mathrm{N}+\mathrm{P}$ treatment, when $\mathrm{N}: \mathrm{P}=7: 1$ and 19:1, respectively. In environments with greater availability of assimilable forms of nitrogen Stelzer and Lamberti (2001) registered higher densities of Gomphonema parvulum. In the present study, these species were more abundant at high total nutrient concentration.

Nitzschia cf. palea was one of the taxa abundant in the treatment with $\mathrm{N}+\mathrm{P}$ addition. In experiment with the addition of nutrients in urban reservoir, Ferragut and Bicudo (2009) found that Nitzschia palea and Monoraphidium arcuatum were the most abundant species in the P treatment, while $M$. contortum was abundant in the $\mathrm{N}+\mathrm{P}$ treatment. According to the author, Nitzschia palea was associated with greater phosphorus concentration. Van Dam et al. (1994) also commented on the preference of Nitzschia palea for more eutrophic environments.

Based on the results of this study we can conclude that $\mathrm{P}$ played a limiting role on the Bacillariophyceae and Cyanobacteria, while on green algae in general, $\mathrm{P}$ and $\mathrm{N}+\mathrm{P}$ treatments showed a marked increase, especially of classes Zygnemaphyceae and Chlorophyceae. In the $\mathrm{N}$ treatment, green algae decreased dramatically, while Cyanobacteria remained steady, demonstrating that 
the Cyanobacteria has the capacity of maintaining itself in changed environments. In addition, the data confirmed that the relative amount of essential nutrients required for development are different and should benefit certain species, since the algal community (density and composition) were positively correlated with nutrient concentrations.

\section{Acknowledgements}

The authors are gratefully to the Pronex Support Program for Excellence Centers, through the Research Project "Productivity in Reservoirs: trophic status and predation relationships" and to "Núcleo de Pesquisas em Limnologia, Ictiologia e Aquicultura" - NUPELIA - for the financial support. To Weliton José da Silva for suggestions and Conselho Nacional de Desenvolvimento Científico e Tecnológico (CNPq) for the productivity fellowships for LR.

\section{References}

BICUDO, DC. 1990. Consideraçóes sobre metodologias de contagem de algas do perifíton. Acta Limnologica Brasiliensia, vol. 3, no.1, p. 459-475.

BIGGS, BJF. 1996. Patterns in benthic algae of streams. In STEVENSON, RJ., BOTHWELL, ML. and LOWE, RL., eds. Algal Ecology: freshwater benthic ecosystems. San Diego: Academic Press. cap. 2, p. 31-56.

BORCHADT, MA. 1996. Nutrients. In STEVENSON, RJ., BOTHWELL, ML. and LOWE, RL., eds. Algal ecology: freshwater benthic ecosystems. San Diego: Academic Press. cap. 7, p. 184-227.

BORGES, PAF., TRAIN, S. and RODRIGUES, LC. 2008. Estrutura do fitoplâncton, em curto período de tempo, em um braço do reservatório de Rosana (ribeirão do Corvo, Paraná, Brasil). Acta Scientiarum, vol. 30, p. 57-65.

BULGAKOV, NG. and LEVICH, AP. 1999. The nitrogen: phosphorus ratio as a factor regulating phytoplankton community structure. Archiv für Hydrobiologie, vol. 146, p. 3-22.

CERRAO, GC., MOSCHINI-CARLOS, V., SANTOS, MJ. and RIGOLIN, O. 1991. Efeito do enriquecimento artificial sobre a biomassa do perifíton em tanques artificiais na Represa do Lobo ("Broa"). Revista Brasileira de Biologia, vol. 51, p. 71-78.

CHORUS, I. and BARTRAM, J. 1999.Toxic Cyanobacteria in Water. Londres: E \& FN Spon. http://dx.doi.org/10.4324/9780203478073

DODDS, WK. 2003. The role of periphyton in phosphorus retention in shallow freshwater aquatic systems. Journal of Phycology, vol. 39, p. 840-849. http://dx.doi.org/10.1046/j.15298817.2003.02081.x

ENGLE, D. L. and MELACK, JM. 1993. Consequences of riverine flooding for seston and periphyton of floating meadows in a Amazon floodplain lake. Limnology and Oceanography, vol. 38, no. 7, p. 15001520. http://dx.doi.org/10.4319/lo.1993.38.7.1500

FERRAGUT, C. and BICUDO, DC. 2009. Efeito de diferentes níveis de enriquecimento por fósforo sobre a estrutura da comunidade perifítica em represa oligotrófica tropical (Sáo Paulo, Brasil). Revista Brasileira de Botânica, vol. 32, no. 3, p. 569-583.

FERRAGUT, C. and BICUDO, DC. 2010. Periphytic algal community adaptive strategies in $\mathrm{N}$ and $\mathrm{P}$ enriched experiments in a tropical oligotrophic reservoir. Hydrobiologia, vol. 646, p. 295-309. http:// dx.doi.org/10.1007/s10750-010-0168-0

FRANÇA, RCS., LOPES, MRM. and FERRAGUT, C. 2009. Temporal variation of biomass and status nutrient of periphyton in shallow Amazonian Lake (Rio Branco, Brazil). Acta Limnologica Brasiliensia, vol. 21, no. 2, p. 175-183.

GOLTERMAN, HL. and CLYMO, RS. 1971. Methods for Chemical - Analysis of Fresh Water. Oxford: Blackwell Scientific Publication.

GOLTERMAN, HL., CLYMO, RS. and OHMSTAD, MAM. 1978. Methods for physical and chemical analysis of freshwaters. Oxford: Blackwell Scientific Publications.

GROVER, JP. 1989. Phosphorus-dependent growth kinetics of 11 species of freshwater algae. Limnology and Oceanography, vol. 34, no. 2, p. 341-348. http:// dx.doi.org/10.4319/lo.1989.34.2.0341

HAVENS, KE., EAST, TL., HWANG, S-J., RODUSKY, AJ., SHARFSTEIN, B. and STEINMAN, AD. 1999. Algal responses to experimental nutrient addition in the littoral community of a subtropical lake. Journal of Freshwater Biology, vol. 41, p. 329-344.

HUSZAR, VLM., SILVA, LHS., MARINHO, M., DOMINGOS, P. and SANT'ANNA, CL. 2000. Cyanoprokaryote assemblages in eight productive tropical Brazilian waters. Hydrobiologia, vol. 424, p. 6777. http://dx.doi.org/10.1023/A:1003996710416

HUSZAR, VLM., BICUDO, DC., GIANI, A., FERRAGUT, C., MARTINELLI, LA. and HENRY, R. 2005. Subsídios para compreensão sobre a limitação de nutrientes ao crescimento do fitoplâncton e perifíton em ecossistemas continentais lênticos no Brasil. In ROLDAM, F., CÉSAR, D. and MARINHO, M., eds. Liçóes em limnologia: fronteiras conceituais. São Carlos: RiMa. p. 243-260.

JACKSON, DA. 1993. Stopping rules in principal components analysis: a comparison of heuristical and statistical approaches. Ecology, vol. 74, p. 2204-2214. http://dx.doi.org/10.2307/1939574 
KELLY, M. and WHITTON, BA. 1998. Biological monitoring of eutrophication in rivers. Hydrobiologia, vol. 384, p. 55-67. http://dx.doi. org/10.1023/A:1003400910730

KONONEN, K. 1988. Phytoplankton summer assemblages in relation to environmental factors at the entrance of the Gulf of Finland during 1972.1985. Kiel Meeresforsch, vol. 6, p. 281-294.

KUOSA, H. 1988. Observations on the taxonomy and ecology of Monoraphidium (Chlorophyceae, Chlorococcales) and Koliella (Chlorophyceae, Ulotrichales) species in the Tvärminne Sea area, SW coast of Finland. Archiv Protistenkd, vol. 135, p. $45-53$.

LEVICH, AP. and BULGAKOV, NG. 1992. Regulation of species and size composition in phytoplankton communities in situ by N:P ratio. Journal Aquatic Ecology, vol. 2, p. 149-158.

LOBO, EA. and LEIGHTON, G. 1986. Estruturas de las fitocenosis planctônicas de los sistemas de desembocaduras de rios y esteros de La zona central de Chile. Revista de Biologia Marinha, vol. 22, no. 1, p. 143-170.

McCUNE, B. and MEFFORD, MJ. 2006. PCORD. Multivariate Analysis of Ecological Data. Version 5.15. Oregon: MjM Software.

MENDES, RS. and BARBOSA, FAR. 2002. Efeito de enriquecimento in situ sobre a biomassa da comunidade perifítica de um córrego de altitude da Serra do Cipó (MG). Acta Limnologica Brasiliensia, vol. 14, no. 2, p. 77-86.

MURAKAMI, EA. and RODRIGUES, L. 2009. Resposta das algas perifíticas às alteraçóes de temperatura e ao enriquecimento artificial de nutrientes em curto período de tempo. Acta Scientiarum. Biological Sciences, vol. 31, no. 3, p. 273-284.

OLIVEIRA, DE., FERRAGUT, C. and BICUDO, DC. 2010. Relationships between environmental factors, periphyton biomass and nutrient content in Garças Reservoir, a hypereutrophic tropical reservoir in southeastern Brazil. Lakes \& Reservoir, vol. 15, p. 129-137.

REYNOLDS, CS., HUSZAR, VLM., KRUK, C., NASELLI-FLORES, L. and MELO, S. 2002. Towards a functional classification of the freshwater phytoplankton. Journal Plankton Research, vol. 24 no. 5, p. 417-428. http://dx.doi.org/10.1093/ plankt/24.5.417

ROSOWSKI, JR. 2003. Photosynthetic euglenoids. In WEHR, JD. and SHEATH, RG., eds. Freshwater algae of North America, ecology and classification. Academic Press. p. 383-422.

SOLORZANO, L. 1969. Determination of ammonia in natural waters by the phenolhypochlorite method. Limnology and Oceanography, vol. 14, p. 799-801. http://dx.doi.org/10.4319/lo.1969.14.5.0799

STATSOFT. 2005. Statistica (data analysis software system). Version 7.1. Statsoft Inc. Available from: <www.statsoft.com>.

STELZER, RS. and LAMBERTI, GA. 2001. Effects of $\mathrm{N}: \mathrm{P}$ ratio and total nutrient concentration on stream periphytic community, structure, biomass, and elemental composition. Limnology and Oceanography, vol. 46, no. 2, p. 356-367. http://dx.doi.org/10.4319/ lo.2001.46.2.0356

UTERMÖHL, H. 1958. Zur Vervolkommung der quantitativen phytoplankton-methodik. Mitteilungen Internationale Verein Limnologie, vol. 9, p. 1-38.

VALDERRAMA, JC. 1981. The simultaneous analysis of total nitrogen and total phosphorus in natural waters. Marine Chemistry, vol. 10, p. 109-122. http://dx.doi. org/10.1016/0304-4203(81)90027-X

VAN DAM, H., MERTENS, A. and SINKELDAM, J. 1994. A coded checklist and ecological indicator values of freshwater diatoms from the Netherlands. Journal Aquatic Ecology, vol. 28, p. 117-133. http:// dx.doi.org/10.1007/BF02334251

WETZEL, RG. and LIKENS, GE. 1991. Limnological analysis. New York: Spring-Verlag. 